\title{
Whatsapp y la desinformación que pasa desapercibida
}

\author{
Pablo Hernández Escayola \\ Coordinador de Investigación Académica de Maldita.es
}

\section{Referencia de este artículo}

Hernández Escayola, Pablo (2022). Whatsapp y la desinformación que pasa desapercibida. En: adComunica. Revista Científica de Estrategias, Tendencias e Innovación en Comunicación, $\mathrm{n}^{0} 23$. Castellón de la Plana: Departamento de Ciencias de la Comunicación de la Universitat Jaume I, 335-337. DOI: http://dx.doi. org/10.6035/adcomunica.6338.

Uno de los mayores canales por los que circula la desinformación en España lo tenemos tan cerca que muchas veces no somos conscientes de su trascendencia. A priori, la imagen de WhatsApp es la de una herramienta que sirve, sobre todo, para estar en contacto con familiares, amigos y personas de confianza. Da la sensación de que los verdaderos problemas de desinformación están en otros espacios, principalmente en las redes sociales abiertas al público general. Pero esa impresión no es cierta. En las redes sociales vemos los bulos circular y a cientos o miles de personas que los reciben e interactúan con ellos. En las aplicaciones de mensajería, nuestro rango de visión es mucho más reducido. Sabemos que parte de los contenidos que circulan por los grupos en los que estamos son pura desinformación, pero tendemos a pensar que eso es algo que sucede a pequeña escala. Sin embargo, WhatsApp tiene características que lo convierten en un lugar ideal para que se mueva la desinformación en España.

Para empezar, aquí su uso es masivo. Según el Digital News Report de 2021, el $83 \%$ de los españoles usa WhatsApp habitualmente. Está muy por encima del 70\% 
de Youtube y del $66 \%$ de Facebook. Además, lo utilizan constantemente personas de todas las franjas de edad. Este mismo informe señala que un $35 \%$ de los españoles lo emplea «para encontrar, ver, leer, compartir o comentar noticias». Este porcentaje coloca a España como el país europeo que más utiliza WhatsApp para informarse. Es decir, millones de españoles usan WhatsApp a diario y para muchos de ellos es una vía relevante de recibir noticias. Estas cifras colocan a WhatsApp muy por encima de otras redes sociales. Por ejemplo, Twitter sólo lo usa habitualmente el 33\% de los españoles y únicamente el 19\% se informa allí. Sin embargo, la visibilidad en Twitter es mucho mayor. Cuando vemos que un bulo es trending topic o recibe miles de retuits sabemos que está teniendo mucho impacto. En cambio, la sensación en WhatsApp es que los contenidos que recibimos forman parte de una conversación privada. Ese efecto de moverse en un entorno de confianza también influye en el tipo de contenidos que se comparten. Hay personas que envían elementos polémicos o comprometidos por WhatsApp que nunca difundirían en redes sociales por miedo a la reprobación de los desconocidos. Sin embargo, precisamente por venir de una persona cercana, es probable que los que reciben esos mensajes les den más credibilidad. Lo muestra, por ejemplo, una investigación de Allington, et al. (2020) que encontró una relación positiva significativa entre creer en teorías de la conspiración y el uso de los amigos y la familia como fuente de información sobre COVID-19.

Además, en las redes sociales públicas se ejerce una labor de moderación que, aunque es mejorable, etiqueta, reduce la difusión e incluso elimina algunos contenidos que se consideran dañinos. En WhatsApp no se puede hacer esa moderación porque los mensajes están encriptados de extremo a extremo. Sólo el emisor y el o los receptores conocen los contenidos que intercambian.

Por lo tanto, nos encontramos con un sistema que permite alcanzar a millones de personas que tienen la sensación de que están tratando con su núcleo de confianza y en el que nadie controla la veracidad de lo que circula. Todas estas características son ideales para que los desinformadores desplieguen sus tácticas y logren sus objetivos. Por eso, WhatsApp es un espacio donde abundan los bulos.

En Maldita.es lo comprobamos a diario gracias a un Chatbot diseñado para interactuar con nuestra comunidad en WhatsApp. Es el primer robot que se puso en marcha en español que emplea la conversación con lenguaje natural automatizado con herramientas de Inteligencia Artificial para atender a los ciudadanos que sospechan de contenidos con posible desinformación compartidos a través de WhatsApp. En el último año, el Chatbot ha recibido 160.000 mensajes, con un promedio de 800 usuarios diarios. Cuando alguno de los usuarios ve un contenido que cree que puede ser un bulo, no tiene más que enviarlo al Chatbot. No da ningún dato de quién se lo ha enviado o cómo ha llegado hasta él, de modo que no se pone en peligro la privacidad de las comunicaciones. La herramienta puede analizar textos, imágenes, vídeos y audios. Si se detecta que le están preguntando por un bulo ya 
desmentido, le envía automáticamente el artículo de verificación. Si no está desmentido, los periodistas de Maldita.es evalúan la alerta y, si cumple con los criterios que hacen pensar que se trata de un bulo potencialmente peligroso, empiezan el trabajo para desmentirlo. A las personas a las que les enviamos un desmentido, les pedimos que no se limiten a leerlo, sino que también lo difundan en los chats donde vieron el bulo. La intención es tratar de que las verificaciones lleguen a los lugares donde está la desinformación para intentar desactivarla.

Gracias a esta herramienta y la colaboración de la comunidad de Maldita.es, podemos hacernos una idea de qué está pasando en WhatsApp. La imagen que se forma con los datos que recopilamos es parcial, pero da pistas muy valiosas sobre la desinformación que se mueve en esos mensajes encriptados. Por ejemplo, la infodemia que llegó con la COVID-19 quedó claramente reflejada en el Chatbot. Si antes de la pandemia recibíamos entre 100 y 150 alertas diarias, cuando el coronavirus apareció en España, la cifra se disparó con picos que alcanzaron las 2.000 consultas al día. Con las alertas de nuestra comunidad podemos saber qué bulos son los más activos en cada momento y sus ciclos de vida, es decir, cuándo aparecen en WhatsApp, cómo van ganando intensidad y cuándo empieza a declinar su difusión. Lógicamente, cuanta más personas utilicen el Chatbot, más datos recogeremos y más precisa es la imagen que conseguimos sobre qué desinformaciones se están viralizando en WhatsApp. Con mejor información, nuestra labor de fact-checkers también será más efectiva. Por eso una de las líneas de actuación más importantes de Maldita.es es promover el uso de nuestro Chatbot y animar al público a que colabore con nosotros a luchar contra la desinformación en un espacio que sólo podemos conocer con su ayuda.

\section{Referencias}

Allington, D., Duffy, B., Wessely, S., Dhavan, N., y Rubin, J. (2021). Health-protective behaviour, social media usage and conspiracy belief during the COVID-19 public health emergency. Psychological Medicine, Vol. 51, nº10. Cambridge: Cambridge University Press, 1763-1769. DOI:10.1017/S003329172000224X

Amoedo, A.; Vara-Miguel, A.; Negredo, S.; Moreno, E.; Kaufmann, J. Digital News Report España (2021). Digital News Report 2021. Consultado el 21 de enero de 2022 en https://www.digitalnewsreport.es/ 